\title{
HOTEL EMPLOYER'S PERCEPTIONS OF EMPLOYING EASTERN EUROPEAN WORKERS: A CASE STUDY OF CHESHIRE, UK
}

\author{
ANDY LYON and DANA SULCOVA \\ Department of Marketing, Tourism and Events Management, University of Chester, Chester, UK
}

\begin{abstract}
This article examines and reveals hotel employer's experiences of employing Eastern European workers in Cheshire, UK. Cheshire has a vibrant and significant visitor economy, with its main tourist destination, Chester, receiving over 8 million visitors a year and has over $30 \%$ of its income generated from the tourism, retail, and hospitality sectors. There is almost full employment in many parts of the region and many employers struggle to fill vacant positions, particularly at the lower skill levels. Many visitor economy employers are now reliant on migrant labor from Eastern Europe. The objectives of this study are to examine the experiences of employers of Eastern European employees and to compare and contrast the contribution of Easter European employees and local employees using six key themes. This article analyzes the outcome of in-depth, one-toone interviews with accommodation employers from Cheshire in northwest UK. The findings suggest that some employers can put forward a number of clear, positive reasons for employing Eastern European workers. These reasons are mainly driven by the migrant workers having certain abilities that British employees lack. On the other hand, however, some employers also suggest that Eastern European workers have certain limitations, which could have implications for the quality of service delivery.
\end{abstract}

Key words: Migrant workers; Quality; Employer perceptions

\section{Introduction}

According to Kandampully (2002), hospitality and tourism constitutes the largest sector of the service economy in almost all developed countries. In the UK, the hospitality industry is a significant growth area of the economy, employing over 2 million people (Foskett, Ceserani, \& Kinton, 2003). However, as the hospitality industry continues to grow it is facing the critical question whether there is a way to achieve a balance between supply and demand in the workforce (Go, Monachello, \& Baum, 1996).

There have been numerous reports highlighting skill gaps and recruitment difficulties in the UK (Confederation of British Industry, 2007; Learning and Skills Council [LSC], 2006a; Leitch, 2006). One potential way of reducing these problems is through what the UK government calls "managed immigration" (Home Office, UK Border Agency, 
2006). In May 2004, 10 Eastern European nations joined the European Union and their citizens have been allowed to come to the UK for the purpose of work. Opening borders to the EU Accession States (Cyprus, Czech Republic, Estonia, Hungary, Latvia, Lithuania, Malta, Poland, Slovakia, and Slovenia) caused the UK to experience the biggest migration wave in its history. According to the government's Home Office statistics, around 30,000 people were expected to come to work in the UK; however, the reality was that 20 times more than that number arrived. Between May 2004 and June 2006, 447,000 people from the Accession States registered to work in the UK. Furthermore, the government estimates that if self-employed people who do not need to register are included, the total is nearer 600,000 (Home Office, UK Border Agency, 2006). While there were significant numbers from Lithuania and Slovakia, the vast majority of migrant workers came from Poland, around $60 \%$, as of 2006 (Learning and Skills Council, 2006a). Hence, immigration can play a vital role in supplying the hospitality industry's labor market. Yet, it is not clear whether international migration in the hospitality industry serves as a positive or negative factor (Choi, Woods, \& Murrmann, 2000). Thus, immigration is receiving the increasing attention of many people involved in the industry.

Cheshire has a vibrant and significant visitor economy, with Chester alone receiving over 8 million visitors a year and generating over $30 \%$ of its income from the tourism, retail, and hospitality sectors; thus, the visitor economy is a major economic driver for the subregion contributing $£ 1.375$ billion in 2004 (Visit Chester and Cheshire, 2007a). The benefits of a strong visitor economy do not stop there as it is particularly important in creating jobs and supporting services and facilities that local communities depend upon. The subregional tourist board Visit Chester and Cheshire (VCC) has ambitious plans to increase Cheshire's visitor economy to $£ 2$ billion by 2015 as part of the long-term vision and strategy involving product quality development and skills and productivity enhancement. The region benefits from a buoyant economy and low unemployment rates in comparison to national averages. Many hospitality employers already struggle to fill vacant positions, particularly at the lower skill levels (Cheshire County Council, 2007; Visit Chester and Cheshire, 2007a). Consequently, many hospitality employers are now reliant on migrant labor.

The majority of recent migrant workers come from Eastern Europe predominantly as a result of the enlargement of the European Union in 2004 and their citizens being given unfettered access to the UK's jobs market. According to Bianchi (2000), economic migration is a pan-European issue and that it is a form of capitalist restructuring. The problem is that for many immigrants English is a second language, or a language that they cannot speak at all. Many struggle with the idea of assimilation as they hope to return home when things are better in their country of origin (Tanke, 2001). Furthermore, migrants tend to be socially and culturally rooted in their country of birth and such attachments are difficult to overcome (Choi et al., 2000). Consequently, concerns appear whether international migration in the hospitality industry serves as a positive or negative factor for the industry. In achieving their objectives of raising the quality of the product and services in Chester and Cheshire, service quality delivery plays an important part of the tourism product (Visit Chester and Cheshire, 2007b). Migrant workers form an integral part of the hotel workforce in Cheshire and they have an impact upon the visitor economy product. Employers need to know of the implications of employing such workers. Therefore, there has been the need for empirical work to be undertaken on the question of the impact of Eastern European workers.

This article investigates employer's perceptions of employing Eastern European employees using key themes: communication skills, teamwork and integration, work ethic and attitude, skills and knowledge, customer service, and key challenges. Presenting the outcomes of a series of interviews with accommodation providers, its purpose is to identify the implications of employing Eastern European workers on these key themes. The interviews were also used to compare and contrast the contribution of Easter European employees and local employees against the themes. Furthermore, the article will identify the lessons that can be learned for employers and tourist boards. 


\section{Perspectives on Migration}

The UK has experienced unprecedented immigration in recent years. The Learning and Skills Council (2006b) undertook an investigation into the geographical distribution of migrant workers and they found the majority of migrants to the UK are based in London and the southeast, although they suggest that Eastern European workers have begun to locate more widely. They also found the largest number of skill-shortage vacancies, as well as hard-to-fill vacancies, was to be found in the northwest, with hospitality being one of the sectors identified. Pemberton and Stevens (2006) were of the view that the Northwest was attractive to migrant workers because of lower cost of living compared to London.

Furthermore, employers in Learning and Skills Council (2006a) research suggested that "UK graduates cannot offer the skills we need, so we have to look abroad" (p. 12). However, some employers did not perceive there to be a major skills gap; rather they pointed to an attitude gap problem, especially in younger British employees (Pemberton \& Stevens, 2006). Yet, both of these reports agreed on the view that migrant workers not only have a very positive attitude towards work but they were also highly educated and skilled, which is in direct contrast to British learners leaving college who often lack basic skills, thus causing concerns about their ability to get the job done (Lowings, 2006).

Tokarzewska (2006) states that in 2006, 72,000 workers from Eastern Europe had entered the hospitality, leisure, travel, and tourism sector. His report goes on to state that Eastern European workers are very enthusiastic, hardworking, and their customer service skills are excellent. Some general features were identified by one hotel employer:

Our experience with migrant workers, and everyone else I have spoken to has shared this, has been great as they are fantastic people to work with. Their work ethic is quite unlike anything we have seen in this country for years and they are really nice people to work with and a lot of them are skilled, having done full university courses, qualified in Poland in different skills. (Tokarzewska, 2006, p. 2)
By contrast, People1st Employer Panel Survey (2006) has revealed that opinions are divided on whether the recent influx of EU Accession State workers has had a positive impact on the UK's hospitality industry. When employers were asked: "How would you rate the customer service skills of EU Accession state workers compared to UK born staff?," only $44 \%$ said better, $42 \%$ stated the same, and $14 \%$ said worse.

However, according to Migrant Workers North West (2007), the general view within the hospitality industry is that the influx of migrant workers over the last 2 years has been nothing but a positive development. The main reasons given for this were that Eastern European workers have a better work ethic than British employees, positive attitude towards work, and they are more skilled and experienced than UK-born staff. Many studies (Learning and Skills Council, 2007; Lowings, 2006; Roberts, 2006) suggest that employers regularly comment on the lack of work ethic and attitudinal issues inherent in young British employees entering the sector. This leaves concerns about their ability to provide excellent customer service. Nevertheless, respondents in tourist areas within Wales, Scotland, and Northern Ireland feel that their customers preferred to be served by local staff (People1st Employer Panel, 2006). This phenomenon might have occurred because local staff members are not only familiar with local cultural mores, but also are well placed to overcome any language communication barriers that might exist (Kandampully, 2002).

This might be the reason for some employers to prefer British workers over migrants, as employers' main concerns of employing Eastern Europeans are related to English language skills and the preconceptions and views of customers. Language skills are therefore an issue of increasing importance. The Learning and Skills Council (2007) argued that language problems were cited as the only disadvantage to employing Eastern European labor. It was concluded by the LSC that the standard of English language had been higher among the first migrant workers to arrive in the post-2004 period than it was with the recent arrivals. Furthermore, the language barrier has been deemed to have had a "knock-on" effect on the management 
and administration time of employers who engaged in employing migrant workers (Dench, Hurstfield, Hill, \& Akroyd, 2006).

People1st Employer Panel (2006) also suggested that employers also claimed difficulties for migrant workers to integrate with domestic staff or workers from other countries. They also found that Eastern European employees would speak their own language in front of customers, who perceived it as rude.

Nonetheless, despite migrants often having wider knowledge of and better experience in the hospitality sector, the quality of service provided by Eastern European workers can be influenced by some characteristics of the industry itself. Wright (1999) stated that organizations engaging in tourism and hospitality (which is well known for its seasonal pattern) tend to employ itinerant workers who do not have the security of permanent employment and salary, and as Robbins and Couter (2005) found they do not identify with the organization or display the commitment that other employees do.

There are also concerns that some employers are simply exploiting those willing to work for low wages, which can have negative influence on the quality of service. Yet, Tokarzewska (2006) argued that this phenomenon had no effect on the quality of service provided by migrant workers as they preferred to be exploited in other countries rather than in their own country. Casciani (2006) explains this in his study on Polish workers in the UK, that "back home in Poland, David was a teacher, taking home the equivalent of $£ 200$ a month. But thrusting flyers in London nets him $£ 600 "$ (p. 1).

It could therefore be argued that Eastern European labor in the UK is prepared to work hard for the minimum wage and provide a high-quality service in the hospitality industry, which offers long and unsociable hours and a lack of real career opportunities (Roberts, 2006). Nevertheless, opinions are divided as to whether this latest wave of Eastern European workers has had a positive impact on the hospitality, leisure, travel, and tourism sector. For example, the Learning and Skills Council (2007) report divided employer's views about migrant workers into three groups: reluctants with negative perceptions of migrant workers, pragmatists with balanced views, and advocates with positive opinions about migrant employees. Their value to the economy is, however, significant as Eastern European employees have become an important source of labor, with most employers believing that businesses would suffer or could not survive without migrant labor (Dench et al., 2006).

Thus, managing a culturally diverse workforce is an important issue not only for the economy as a whole, but also for managers within organizations. According to Walsh (1995), there are quantifiable benefits to employing an ethnically diverse workforce, such as reduced absenteeism and reduced staff turnover. Iles (1995) develops this argument by stating that an internationally diverse workforce can be an organizational asset and resource if managed skillfully. For managers, the softer benefits of a diverse workforce in terms of increased morale, better teamwork, and greater job satisfaction can be difficult to prove (Kandola \& Fullerton, 1994). Maxwell, McDougall, and Blair (2000) see that for service sector managers it is the harder, measurable benefits such as reduced staff turnover, decreases in absenteeism, and increases in product/service quality that appeal. They also state that a culturally diverse workforce is a significant opportunity for the hotel sector and if senior managers are committed and willing to be trained and to train in all aspects of diversity management, they, the organization, and its employees will reap the benefits. This approach is supported by Nykiel (1997), who states that in order to increase the desirability of the workplace and attract new employees while retaining the best ones, all employees need to be trained in diversity management and cultural acquisition.

\section{Methodology}

Ghauri and Gronhaug (2002) argue that the research problem and its purpose determine which methods and techniques are most suitable to use. Considering the research topic-employers' perceptions of Eastern European employees-against the six key themes and the methodologies used by previous researchers, one-to-one interviews were deemed to be the most appropriate research 
method for the purpose of the research. Inside Out England (2006) used one-to-one interviews to discover how people in the UK perceive migrant workers, as did the Learning and Skills Council (2006b), Pemberton and Stevens (2006), and Dench et al. (2006). By contrast, the People1st Employer Panel (2006) study was undertaken using a questionnaire, having only a $15 \%$ response from hospitality employers. In consultation with VCC, the hospitality industry interviews were chosen over questionnaires due to the potentially low response rate and relatively small sample size. Consequently, this research was conducted using one-to-one in-depth interviews, using the grounded theory approach to ascertain the perceptions of employers on the implications of employing migrant workers on service delivery. Corbin and Strauss (1990) stated that the aim of grounded theory is not to generalize findings to a broader population per se, but the sampling methods used draw out the samples key concepts, their properties, dimensions, and variations. As a result, qualitative research methods (grounded theory) were associated with "face-to-face" contact with people in the research setting (Eldabi, Irani, Paul, \& Love, 2002).

The research sample consisted of 10 three- and four-star hotels in the Cheshire area. Seven hotels are in the tourist "honey-pot" of Chester in Cheshire and the other three are in the wider region. The ownership of the hotels varies; three are privately run and seven are part of larger chains. All hotels cater to business and leisure visitors, although the ones in Chester deal with a slightly larger leisure market. The hotels were chosen through consultation with VCC as those knowingly employing migrant Eastern European labor. These workers are employed in a variety of positions both in housekeeping and in those dealing face-to-face with customers. All the hotels rely heavily on Eastern Europeans with approximately one quarter being from this region. A series of semistructured and unstructured interviews was carried out with the general managers of the hotels regarding their perceptions of:

- Top five criteria of good customer service.

- How are Eastern European employees performing against these criteria?
- How are British employees performing against these criteria?

- Which group of employees deliver better customer service and why?

This range of areas was subsequently discussed with each employer through face-to-face interviews. The questions were both semistructured and open-ended to encourage free expressions of interviewees' thoughts and feelings. The interviewer applied probing and paraphrasing to facilitate recalls and allow delayed responses. As there were number of points of interest made in this respect, it was therefore possible to classify responses under six broad themes:

- Communication skills

- Team work and integration

- Work ethic and attitude

- Skills and knowledge

- Customer service

- Challenges-lack of local employees, employees' referrals, and labor turnover.

The data were systematically analyzed once they had been disaggregated into meaningful and related parts or categories. Guided by the structure of the interviews and the research aim of this project, data were categorized into the six main themes listed above. The analysis followed the guidelines of grounded theory approach of Strauss and Corbin (1998), which allows a theoretical concept or model to be outlined through the scrutiny of data rather than through testing preconceived hypotheses developed from the literature. The first step was to evaluate the data, looking for relevant and reoccurring themes. These were then categorized and assigned labels from which groupings emerged as a result. It is from these groupings and themes that propositions were introduced and developed.

Findings

\section{Communication Skills}

According to the Learning and Skills Council (2006b) and Pemberton and Stevens (2006), the primary difficulty faced by all employers in terms of employing migrant workers relates to language 
barrier. Similarly, participants in this research expressed the perception that the biggest drawback in employing Eastern European workers was language limitation. It was generally felt that due to the lack of understanding of English, migrant workers took longer to go through the training process and, consequently, made the process more difficult for the employer.

However, this was suggested only by the organizations where training was a very difficult and diverse process including health and safety tests, computer tests, watching educational programs, and so on. Moreover, two of the employers suggested that it can be even easier to train Eastern European workers as they have a positive attitude towards work, better concentration, and an extreme drive to become good at their job. It has been claimed by one of the participants that:

Migrant workers are more determined to become good at the job so they will study harder and dedicate it more of their free time. (Hotel Manager B)

Nevertheless, another employer cited that:

Eastern European workers can often take advantage of the perceived language barrier, claiming that they do not understand what their manager wants them to do, but in fact, they do understand very well and they know exactly what is being desired of them to do. (Hotel Manager D)

Furthermore, interviewees in general highlighted that migrant workers had difficulties with the understanding of local or industry terminology such as "pint of snakebite," eggs served "sunny side up," and so on. Thus, it was concluded that in spite of Eastern European workers being very enthusiastic about and very fast at learning English, their gaps in industry-related language terminology had an impact on service delivery. Consequently, nearly a half of the employers claimed that they received negative comments, regarding Eastern European workers, from customers, with one such comment being:

It is here like being in the gulag. The waitress did not understand what I was saying. Do you not employ people who speak English? (Hotel Manager A)
Yet, examples were also cited of customers being extremely happy, suggesting that migrant workers have excellent English and they are very polite with customers.

By contrast, a number of practitioners also raised concerns about the fact that Eastern Europeans can sometimes be very direct and say something that in the UK might be perceived as too forward or even rude. One of the interviewees noticed that due to their "broken" English (they do not know what to say and how to say it) Eastern European workers might sound more abrupt than British employees. Unfortunately, this can cause a serious problem, as "effective communication with customers can be a winning business strategy in the service sector" (Go et al., 1996, p. 72). Poon (1998) supports this statement, suggesting that in Europe, one of the main trends uncovered by the European Travel Data Center is the need for personal attention and more communication during any customer service. She argues that consumers want to be served by people whom they can talk to as they may ask about the ingredients used to prepare their meals or about the local flora and fauna. They want staff who can answer their questions correctly, responsively, and with a human touch.

\section{Team Work and Integration}

Effective communication in the workplace is as important as effective communication to customers because it promotes goodwill, trust, and personal satisfaction among everyone. It builds respect and rapport between employees and creates a more team-oriented environment (O'Shannessy, Minett, \& Hyde, 2002). However, Go et al. (1996) argue that for most individuals, effective communication skills such as supportive communication and active listening do not come naturally. Consequently, some of the employers were of the view that British workers, despite speaking good English, appear to have problems with internal communication, which causes further problems with team working. What is more, in their research Pemberton and Stevens (2006) argue that low integration may be exacerbated by British workers ignoring or even excluding migrant employees when talking, socializing, or bantering. 
It could therefore be the case that it is the Eastern European workers behavior that increases the risk of creating problems with integration and team working. Two of the respondents confirmed the view that migrant workers mixed in well with the British and that they made an effort to work all together as a team. Yet, more than a half of interviewees stated that Eastern European employees do not mix well with the British workers, suggesting that:

At work, they keep socializing with their own ethnic groups and furthermore, they keep talking their own language in front of British colleagues who feel they are being spoken about. (Hotel Manager F)

In the Learning and Skills Council (2006c) report, one of the participants claimed that it would help to improve team work if Eastern European workers socialized more with the British employees. This was also found to be the case in a study of the opportunities and challenges of managing cultural diversity in Northern Ireland, whereby better integration and socialization between local and migrant workers was a key recommendation (Devine, Baum, Hearns, \& Devine 2007).

\section{Work Ethic and Attitude}

According to Learning and Skills Council (2006c) and Pemberton and Stevens (2006), the primary reason given by employers for employing migrant workers was their positive attitude to work. This view was strongly mirrored by employers in the Chester accommodation sector. Eastern European workers were generally perceived to have a stronger and more positive work attitude and ethic than UK-born employees. Migrant workers were seen as very hard working, dedicated, reliable, punctual, obedient, respectful of authority, highly committed, and willing to do any kind of job. Conversely, British workers were perceived as less enthusiastic with a very poor attitude towards work, less willing, and even lazy. They had higher levels of sickness and low commitment in terms of not turning up for work or had poor timekeeping.

One of the employers identified the problem with the British attitude as a lack of understanding of what luxury is about.
For British employees their employment represents "just a job." They think that when they speak English, they are better than Eastern Europeans and do not make any effort to provide a high quality service. And this can have serious implications for customers' satisfaction. (Hotel Manager D)

Looy, Gemmel, and Dierdonck (2003) argue that there is an inherent link between customers' satisfaction with service quality and employees' behavior-the way employees feel and act has an impact on the quality of the service delivered. Therefore, a positive attitude is essential, as employees feeling enthusiastic about their job not only communicate this feeling both verbally and nonverbally, but they are also eager to work hard towards satisfying their customers.

Moreover, for a company to succeed, it is necessary for employees to have a desire to do their best (Hollinshead, Nicholls, \& Tailby, 2003). The vast majority of the employers spoken to claimed that unlike British employees, Eastern European workers are more determined to succeed, more eager to please, very single minded in their ambition to excel in the job and to serve the customer the best they can.

According to Ford and Heaton (2000), there really is something different about outstanding hospitality employees. They use the term "lovers" because they love to provide great service and, consequently, can provide their guest with a "feel good" level of service. It feels good because the server somehow connects with the guest in a way that builds a relationship, which makes the guest feel that there is something special and memorable about the experience. Unfortunately, they estimate that people who love to serve represent only 1 in 10 of the available workforce. Three interviewees tended to agree stating that:

British people love to be served but they do not like to serve. (Hotel Managers A, F, J)

The problem is, as Bach and Sisson (2000) report, that the UK is now predominantly a service economy, which by its nature requires not only a workforce that loves to serve but also one that is flexible. Flexibility, however, is an ambiguous concept placing pressure on employees (Gennard 
\& Judge, 1999). Therefore, it is very much valued by employers that migrant employees are able to work flexible and longer hours.

Migrant workers are happy and willing to do a lot more hours, work longer hours than British and are not complaining that the job is hard. They are never off sick and they take any extra work. (Hotel Manager G)

Conversely, according to the responses of interviewees, British employees are less willing to work flexibly; they are not willing to work as hard and to do as many hours and often complain how hard the job is. It can be argued that this major difference in the work attitudes between migrant and British workers can be attributed to their cultural background. As Kusluvan (2003) states, the culture and groups people belong to shape their thoughts, feelings, and behavior by setting acceptable and unacceptable norms. Consequently, cultural background and differences can have significant implications for people's attitudes towards work and their employing organization (Hollinshead et al., 2003). Part of the problem, it was suggested, was that migrant employees became bored with their jobs as their knowledge and skills were far above those required. It was noted by a few employers who shared the view of one respondent in that:

Once Eastern European workers spent some time doing the job, they knew how to do the job, they found their way around their duties, became fed up with the job and lost their enthusiasm and willingness. (Hotel Manager E)

This issue was also highlighted by Iles (1995), who states that a diverse workforce can be less of an asset where tasks are seen to be routine in nature.

\section{Skills and Knowledge}

A large proportion of migrant hospitality employees are workers with other formal educational backgrounds (Hjalager \& Andersen, 2001). They take up jobs in the hospitality industry due to their lack of English language. Some employers felt that overqualified migrants in menial jobs are likely to become dissatisfied and effectively as- sume the mindset of an unwilling UK worker or once they had overcome the language barrier they would be seeking work at higher levels (Learning and Skills Council, 2006). Most of the interviewed employers shared the same opinion, fearing that both scenarios could result in unskilled positions going unfilled.

This is because there is a widely held view among the general public-at-large, who have a negative image of the attractiveness of the hospitality and tourism sectors as a career choice (Choi et al., 2000). Nonetheless, according to Dench et al. (2006), migrant workers perceive the hotel and catering sector as a good industry to work in and they want to gain more experience in the sector. Thus, a common comment by participants was that attracting and retaining well-educated and skilled British workers is a chronic problem for the hospitality and tourism industries. Some of the employers argued that this is caused by the education gap in the UK.

The problem in the UK is that something like this is not seen as a profession and therefore there is lack of knowledge and qualification among British employees. (Hotel Manager I)

In Eastern Europe there are many highly professional colleges, such as Hotel Academies and Business and Tourism Schools, that provide students with valuable hospitality industry-related skills and knowledge (Fogel, 1990; Matlay, 2001). Hence, many of the Eastern Europeans are very highly educated with excellent industry knowledge. Service industry employers seek not only well-educated workers, but also workers with personal characteristics likely to make them interact and perform effectively. Thus, especially in the hospitality industry, sociability, friendliness, drive, honesty/integrity, conscientiousness, and adaptability are more important selection criteria than knowledge and skills in the name of customer care (Lucas, 2004).

\section{Customer Service}

According to the majority of respondents in the research sample, both sets of employees, British and Eastern European, have all of these essential characteristics. 
Both nationalities are friendly, smart, and sociable with the customers, well mannered and smiley. If they were not, they would not work here. (Hotel Manager C)

Yet, there are differences between these two groups with regards to customer integration. It could be argued that this is again due to the cultural differences because, in particular, if the service provider and the customer come from different cultural backgrounds, there can be serious implications with regard to that most important of hospitality issues - the perception of service delivery (Kandampully, 2002).

Consequently, some employers were of the view that British employees have prominent customer service experience, in terms of knowing the customer market better than migrant workers. British employees may be more pleasant towards the customer as they know the customer's habits better and they can speak more to the customer and better serve their needs. One of the employers mentioned that:

Pleasing the customer is easier for a British member of staff as the British employees are better at knowing what the customers want. (Hotel Manager E)

Interestingly, another interviewee claimed that:

British employees do not have the advantage of knowing the customer better because when Eastern European workers have the basic English they will get a strong bond with the customers because of the very positive Eastern European attitude towards work and serving a customer. (Hotel Manager B)

However, despite the advantages and disadvantages cited, employers expressed no real preference for either migrant or domestic workers, suggesting that both nationalities provide the same high-quality service for British customers, although two employers noted that Eastern European employees easily outperform their British colleagues.

Tanke (2001) notes there is a growing cultural diversity within hospitality consumers who demand some adjustments in service styles and qualities. Therefore, as society becomes more global, the customer-contact employee will be required to know and recognize an increasingly diverse range of languages, customs, symbols, or nonverbal messages in order to provide the higher levels of service expected (Olsen, West, \& Tse, 1998). Consequently, employers taking part in this research appreciated the added benefit of employing migrant workers - multilingual workers were able to speak, relate to, or attract some non-Englishspeaking customers.

Yet, there were also problems with Eastern European employees speaking among themselves in their own language, which was perceived negatively by British customers who saw it as rude. In order to overcome this problem, the hiring of local labor can be an important strategy in decreasing cultural problems. Local staff members are not only familiar with local cultural mores, but are also well placed to overcome any language communication barriers that might exist (Kandampully, 2002). However, employing local staff creates some challenges for employers in the UK.

Challenges: Lack of Local Employees, Employee Referrals, and Labor Turnover

A particular cause for concern, noted by practitioners interviewed, was of the shortage of and difficulty with recruiting local employees. One employer in Pemberton and Steven's (2006) research claims that the main reason for employing migrant workers is a shortage of local candidates. Understandably, a high supply of Eastern European workers "takes a huge weight off the employers" shoulder as they can rely on many application forms coming from the migrant workers.

Moreover, from a recruitment perspective, migrant employees will often have a pool of similar friends or family members as potential candidates for future vacancies. Gennard and Judge (1999) noted that referrals by current employees can represent a large source of employees for many hospitality organization and, as Ford and Heaton (2000) note, a bonus of this strategy is that existing employees who bring in their friends feel responsible for them and their performance as they exert positive peer pressure and encourage the new employees they sponsored to do well, all to the organization's benefit. 
However, according to participants in this study, a few organizations feel conscious about employing a significant number of migrant workers and few British workers. It could be argued that this is because employers in tourist areas feel that their customers prefer to be served by local staff (People1st Employer Panel, 2006). Furthermore, employing only migrant workers can lead to problems with staff turnover because, as they are friends or family, they all start working at the same time, but they also want to leave all at the same time, causing staff shortages.

Moreover, a vast majority of the employers interviewed noted that Eastern European staff stay in the employment only for a short period of time -1 or 2 years.

Some of the migrant workers stay only for as long as their English is improved and then they move on to better jobs. Others just stay for the time long enough for them to earn a lot of money and then take them back home. (Hotel Manager F)

Yet, a few of the employers suggested that migrant workers do not make the labor turnover any higher than it would normally be. Looy et al. (2003) suggest that many hospitality and tourism organizations experience persistently high rates of staff turnover. Rowley and Purcell (2001) support this statement, claiming that in the context of the $\mathrm{UK}$, a job tenure of 18 months to 2 years has been accepted as normal labor turnover, even by the best practice employers.

\section{Conclusions}

Dench et al. (2006) revealed in their report that the language barrier has been deemed to have had a "knock-on" effect on the management and administration time of employers who engaged in employing migrant workers. A similar phenomenon has been noted by employers who participated in this research.

Participants in this research expressed the perception that the biggest drawback in employing Eastern European workers was language limitation. Furthermore, interviewees in general highlighted that migrant workers had difficulties with understanding of local/industry terminology, which had impact on the service delivery. A num- ber of practitioners also raised concerns about the fact that Eastern Europeans have a tendency to be direct when they speak and say something that could be perceived as too forward or even rude in the UK.

The main advantage of hiring migrant workers for these employers was that migrants were perceived to have a stronger and more positive work attitude and ethic than UK-born workers. Migrant workers were seen as very hard working, dedicated, very reliable and punctual, obedient, and respectful of authority. The interviewees stated that in general they were highly committed and would undertake jobs or tasks that some UK employees may consider beneath them.

The majority of the employers spoke to claim that, unlike British employees, Eastern European workers are more determined to succeed, more eager to please, and very ambitious. They wish to excel in their job and to serve the customer the best they can. Conversely, British workers were perceived as less enthusiastic with a poor attitude towards work, less willing, and even lazy. The respondents found that they had higher absentee rates and lower commitment in terms of not turning up for work and often had worse punctuality than Eastern Europeans. Thus, as employee attitudes and behavior influence service quality and customer satisfaction, it could be argued that Eastern European workers can in some situations provide better customer service.

However, some employers were of the view that British employees have better customer knowledge than migrant workers. It was suggested that British employees may be more pleasant towards the customer as they know the customer's habits better and they can speak more to the customer, thus achieving more of a rapport with the customers than Eastern Europeans, although some employees said migrant workers can achieve a strong bond with the customers because of their very positive attitude towards work and customer service.

Many of the Eastern European workers are very highly educated with better knowledge of the job, filling the skills and education gap of UK-born workers. Moreover, migrant workers are also filling the "right attitude" gap left by British employees. Nevertheless, their English language skills are 
felt to be the key issue for migrant workers and the biggest barrier to such individuals utilizing their existing skills and qualifications within the workplace.

However, despite the advantages and disadvantages cited, the majority of employers expressed no real preference for either migrant or domestic workers, suggesting that both nationalities provide the same high-quality service for customers. Both groups were found to be generally friendly, smart, well mannered, and sociable with the customers. Yet, two employers noted that Eastern European employees, due to their very positive attitude and the extreme drive to please customers, significantly outperform their English colleagues.

\section{Recommendations for Industry}

Some employers suggested a few recommendations that would be of a great help to them. First, there was felt to be potential to provide employers with assistance in translating foreign qualifications into UK equivalents. Second, the majority of respondents indicated that they would like support with respect to training and translation of health and safety documents as well as documents of employment law. One employer suggested that bilingual Welfare Officers could specialize in dealing with some of the support issues just mentioned.

As stated by Maxwell et al. (2000), training is imperative in all aspects of managing a culturally diverse workforce. The employment of workers in the hospitality sector has raised new challenges in this area. Cultural awareness training for all workers is needed, particularly at induction, involving not only how to deal with culturally different colleagues, but also clients. Managers also need to be trained in order that they too can develop their staff. Language development, particularly in the field of hospitality, is imperative in order to try to minimize misunderstandings between customers and staff, but also to allow more effective communication to take place between team members. As part of the training programs, team-building exercises could be undertaken to bring workers from different backgrounds together.

One of the greatest challenges lies in altering the image of the hospitality sector in the UK in order to persuade potential local entrants that the industry has valuable and rewarding career opportunities. Only time will tell if the gaps in the labor market will continue to be filled by migrant labor.

\section{References}

Bach, S., \& Sisson, K. (2000). Personnel management in perspective. In S. Bach \& K. Sisson (Eds.), Personnel management (3rd ed., pp. 2-43). Oxford: Blackwell.

Bianchi, R. V. (2000). Migrant tourist workers: Exploring the 'contact zones' of post-industrial tourism. Current Issues in Tourism, 13(2), 107-133.

Casciani, D. (2006). So you are Polish and want a job... Retrieved December 2, 2006, from http://news.bbc. co.uk/2/hi/uk_news/5376602.stm

Cheshire County Council. (2007). Chester enterprise centre. Retrieved April 1, 2007, from http://www.cheshire. gov.uk/Business/Businessgeneration/chester.htm

Choi, J., Woods, R., \& Murrmann, S. (2000). International labour markets and the migration of labour forces as an alternative solution for labour shortages in the hospitality industry. International Journal of Contemporary Hospitality Management, 12(1), 61-66.

Confederation of British Industry. (2007). Shaping up for the future. The business vision for education and skills. Retrieved April 2, 2007, from http://www.cbi.org.uk/ pdf/skillssuftf0407.pdf

Corbin, J., \& Strauss, A. (1990). Grounded theory research: Procedures, canons, and evaluative criteria. Qualitative Sociology, 13(1), 3-21.

Dench, S., Hurstfield, J., Hill, D., \& Akroyd, K. (2006). Employer's use of migrant labor. London: Home Office.

Devine, F., Baum, T., Hearns, N., \& Devine, A. (2007). Managing cultural diversity: Opportunities and challenges for Northern Ireland hoteliers. International Journal of Contemporary Hospitality Management, 19(2), 120-132.

Eldabi, T., Irani, Z., Paul, R. J., \& Love, P. E. D. (2002). Quantitative and qualitative decision-making methods in simulation modeling. Management Decision, 40, 64-73.

Fogel, D. (1990). Management education in Central and Eastern Europe and the Soviet Union. Journal of Management Development, 9(3), 112-134.

Ford, R., \& Heaton, Ch. (2000). Managing the guest experience in hospitality. Albany, NY: Delmar/Thomson Learning.

Foskett, D., Ceserani, V., \& Kinton, R. (2003). The theory of catering (10th ed.). London: Hodder \& Stoughton.

Gennard, J., \& Judge, G. (1999). Employee relations (2nd ed.). Trowbridge: The Cromwell Press.

Ghauri, P., \& Gronhaug, K. (2002). Research methods in business studies. A practical guide (2nd ed.). Harlow, Essex: Pearson Education Limited.

Go, F., Monachello, M., \& Baum, T. (1996). Human resource management in the hospitality industry. New York: John Wiley \& Sons, Inc. 
Hjalager, A., \& Andersen, S. (2001). Tourism employment: Contingent work or professional career. Employee Relations, 30(2), 115-129.

Hollinshead, G., Nicholls, P., \& Tailby, S. (2003). Employee relations (2nd ed.). Essex: Pearson Education Limited.

Home Office, UK Border Agency. (2006). Accession monitoring report May 2004-March 2006. Retrieved December 12, 2006, from, http://www.ukba.homeoffice. gov.uk/sitecontent/documents/aboutus/reports/accession _monitoring_report $/$ report $7 /$ may04mar06.pdf? view $=$ Binary

Iles, P. (1995). Learning to work with difference. Personnel Review, 24(6), 44-60.

Inside Out England. (2006, November 13). Eastern European immigration survey, BBCTV.

Kandampully, J. (2002). Service management-the new paradigm in hospitality. Frenchs Forest: Pearson Education Australia Pty Limited.

Kandola, R., \& Fullerton, J. (1994). Managing the mosaic. London: IPD.

Kusluvan, S. (2003). Managing employee attitudes and behaviours in the tourism and hospitality industry. New York: Nova Science Publishers.

Learning and Skills Council. (2006a). Skills in England 2005, Vol.1 key messages. Retrieved April 2, 2007, from http://readingroom.lsc.gov.uk/Lsc/2006/research/ commissioned/nat-skillsinengland2005vol1-re-july2006. pdf

Learning and Skills Council. (2006b). National employers skills survey 2005: Key findings. Retrieved April 2, 2007, from http://readingroom.lsc.gov.uk/LSC/2006/re search/commissioned/nat-nationalemployersskillssurvey 2005keyfindings-re-june2006.pdf http://www.lsc.gov.uk

Learning and Skills Council. (2006c). Employer perceptions of migrant workers research report. Retrieved April 2, 2007, from http://readingroom.lsc.gov.uk/Lsc/ National/nat-employersperceptionsofmigrantworkers.pdf

Learning and Skills Council. (2007). Migrant workers and the labor market. Retrieved April 2, 2007, from http:// readingroom.lsc.gov.uk/lsc/National/nat-migrantworkers andthelabourmarket.pdf

Leitch, S. (2006). Prosperity for all in the global economy - world class skills. London: HMSO.

Looy, B., Gemmel, P., \& Dierdonck, R. (2003). Service management - an integrated approach (2nd ed.). Essex: Pearson Education Limited.

Lowings, A. (2006). It never used to be like this. An analysis of the view's of lecturers. Retrieved March 27, 2007, from http://www.people1st.co.uk/research/themes

Lucas, R. (2004). Employment relations in the hospitality and tourism industries. London: Routledge.

Matlay, H. (2001). Entrepreneurial and vocational education and training in central and Eastern Europe. Education and Training, 43(8/9), 395-404.

Maxwell, G., McDougall, M., \& Blair, S. (2000). Managing diversity in the hotel sector: The emergence of a service quality opportunity. Managing Service Quality, 10(6), 367-373.

Migrant Workers North West. (2007). Challenges and Opportunities Conference, February 9, 2007.

Nykiel, R. (1997). Enhancing quality through diversity. Journal of Hospitality and Leisure Marketing, 4(4), 65-70.

Olsen, M., West, J., \& Tse, E. (1998). Strategic management in the hospitality industry. New York: John Wiley \& Sons.

O'Shannessy, V., Minett, D., \& Hyde, G. (2002). The road to tourism-Skills for the new professional. Frenchs Forest: Pearson Education Australia Pty Ltd.

Pemberton, S., \& Stevens, C. (2006). Supporting migrant workers in the North West of England. Merseyside Social Inclusion Observatory. Retrieved from http://www. liv.ac.uk/civdes/msio/Briefing_Papers/MSIO_PR_03_Executive_Summary.pdf

People1st Employer Panel. (2006). Employer panel quarterly survey: June-August 2006. Retrieved December 2, 2006, from http://www.people1st.co.uk/webfiles/doc/ Employer\%20Panel\%20Results\%20-\%20Q1.pdf

Poon, A. (1998). Tourism, technology, and competitive strategies. Wallingford-Oxon: CABI Publishing.

Roberts, K. (2006). What do they really think? Students attitudes towards career prospects in hospitality, travel, and tourism industry. Retrieved March 27, 2007, from http://www.people1st.co.uk/research/themes

Robbins, S. P., \& Couter, M. (2005). Management (8th ed). New Jersey: Pearson Education Limited.

Rowley, G., \& Purcell, K. (2001). "As cooks go she went": Is labor churn inevitable? International Journal of Hospitality Management, 20(2), 163-185.

Strauss, A., \& Corbin, J. (1998). Basics of qualitative research (2nd ed.). Thousand Oaks: Sage Publications.

Tanke, L. (2001). Human resources management-for the hospitality industry (2nd ed.). United States: Thomson Learning.

Tokarzewska, M. (2006). Is Poland facing a brain drain? A personal perspective on the impact of Polish workers coming to work in the sector. Retrieved November 27, 2006, from http://www.people1st.co.uk/research.themes

Visit Chester and Cheshire. (2007a). Key highlights of visit Chester \& Cheshire Business Plan 2007/8. Retrieved April 01, 2007, from http://www.visitchesterandche shire.co.uk/admin/files_upload/832502/Business\%20Plan \%20Summary\%2007\%2008.doc

Visit Chester and Cheshire. (2007b). Visitor economy conference. Retrieved April 1, 2007, from http://www.visit chesterandcheshire.co.uk

Walsh, J. (Ed.). (1995). Mastering diversity: Managing for success under ADA \& other anti-discrimination laws. Santa Monica, CA: Merritt Publishing.

Wright, J. N. (1999). The management of service operations. London: Cassell. 